\title{
Nyerhvervet inkunabel med lang historie
}

I efterairet 2015 fik undertegnede en henvendelse om evt. køb af en uhyre sjalden inkunabel i samlingen efter en kendt, just afdod bogsamler. Inkunablen havde en proveniens, der kunne spores langt tilbage i den danske bog-og bibliotekshistorie. Jeg slog straks til og undrede mig over, hvorfor den ikke for langst var endt i Det Kongelige Biblioteks inkunabelsamling, idet jeg troede, at mine forgangere, bl.a. i forbindelse med gennemgangen af de gamle stifts- og skolebiblioteker efter den 1. verdenskrig, for langst havde sikret, at disse sjaldne tryk blev overfort til Det Kongelige Bibliotek. ${ }^{1}$ Jeg bad derfor boghistorikeren Karsten Christensen om at undersøge, hvorfor dette ikke var sket, herunder hvad der var sket med inkunablen i det 20. arbundrede.

Erland Kolding Nielsen

af Karsten Christensen, domicileret forskningsstipendiat, cand.phil., tidl. Københavns Universitet

I november 2015 købte Det Kongelige Bibliotek (KB) i boet efter den danske bogsamler Jørgen Jark en inkunabel, dvs. en bog, trykt før 1501. Inkunabelkøb er ikke hverdagskost - selv for KB. Det er mere end 10 år siden, det skete sidst, og det internationale prisniveau taget $\mathrm{i}$ betragtning $\mathrm{kan}$ det ikke undre. Denne gang er der tale om et "missale ad usum romane curie", en katolsk messehåndbog, trykt i Lyon og udgivet den 27. november 1495. Udgaven er katalogiseret i British Library Incunabula Short Title Catalogue (ISTC) som nr. im00710100 og i Gesamtkatalog der Wiegendrucke (GW) nr. M23926. Det kan indholdsmæssigt ikke siges at være noget oplagt køb. KB's rige inkunabelsamling har vel ca. 30 missaler i forvejen, og flere af disse er indholdsmæssigt også i den særlige version beregnet til brug ved den romerske kurie. Trykkeriet, forestået af Petrus Mareschal og Barnabas Chaussard, er også repræsenteret med et par udgaver i inkunabelsamlingen, dog med andre tryktyper, så begrundelsen for anskaffelsen af denne, desværre også noget ukomplette bog, er da også først og fremmest en anden, nemlig eksemplarets historie.

Bogen har en lang fortid i Aalborg. Den stod blandt en del andre bøger i Skt. Budolfi kirke (dokumenteret i katalog fra 1627), hvor man ca. 1570 grundlagde et efterreformatorisk kirkebibliotek. Dette biblioteks videre skæbne er velkendt. Det flyttedes i 1718 af den daværende biskop Frans Thestrup til det gamle Helligåndskloster, der fortsat fungerede som byens hospital og fattigstiftelse og på det tidspunkt tillige husede byens latinskole. Her skabte biskoppen et nyt bibliotek til den studerende ungdoms brug med udgangspunkt i bøgerne fra Skt. Budolfi, suppleret med egne og andres gaver. Efter Thestrups død gik også dette bibliotek i glemmebogen og forfaldt, men blev genfundet ved etableringen af Aalborg Stifts- og Amtsbibliotek i 1818. Ved den lejlighed blev et stort antal af de gamle bøger, herunder missalet, repareret og genindbundet i beskedne, men pæne 


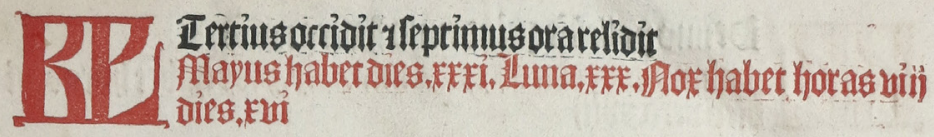

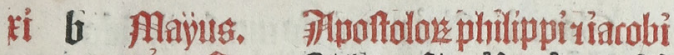

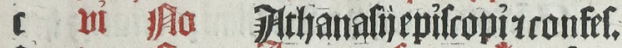

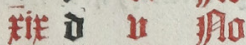

biij $P$ iiij 1 月a

f iij 1 月o

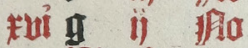

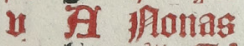

bi niti 3100

tiii c vii 3 (ji

ii a ni 3 保

p $\mathfrak{i}=y^{2}$

E f iiij 3 औi

Ii ii 30

miiif

(xii) ti Jouta

c Fuii kl

Fui is tat th

iiii $\mathfrak{f} F$ kit

f kilii lil

(ii) g $\mathrm{kii}$ if

i A tii kil

bi

ite c k kil

a if

Fuij $\mathfrak{p}$ uiij $k 1$

ui $\mathfrak{f}$ wij $\mathrm{kl}$

If it th

kiliiif it ki

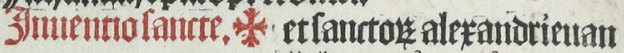

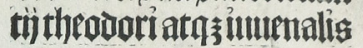

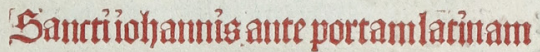

I) Mpparitiofantimuichadis

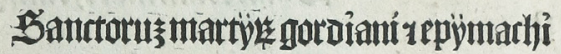

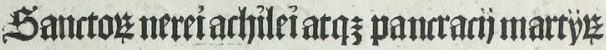

Santribuniffacij mattyris.

\section{3)umii}

Eantcte potrutriane uirgimita

Sol int geminus

Salutribernarimicouffofforist.

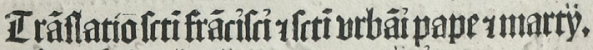

Santrieletuthertij pape ymartyris

Santrilohaumig pape zmartivitis.

iij b iiij $\mathrm{kl}$

c iif $\mathrm{HI}$

If is if $\mathrm{ki}$

Santrif folicis pape y mattivitis

Santre petronille nirginis.

Missalet indledes med den romersk-katolske liturgiske evighedskalender, hvor helgendagene er opfort - her for maj måned. Ud fra bogstavet i 2. kolonne ("sondagsbogstavet") kan ogsa ugedagen aflases, när blot man ved, hvilket bogstav den 1. januar i et givet ä er tildelt.

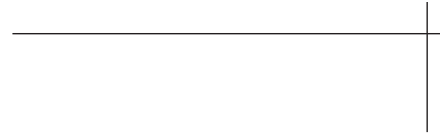

iii) 


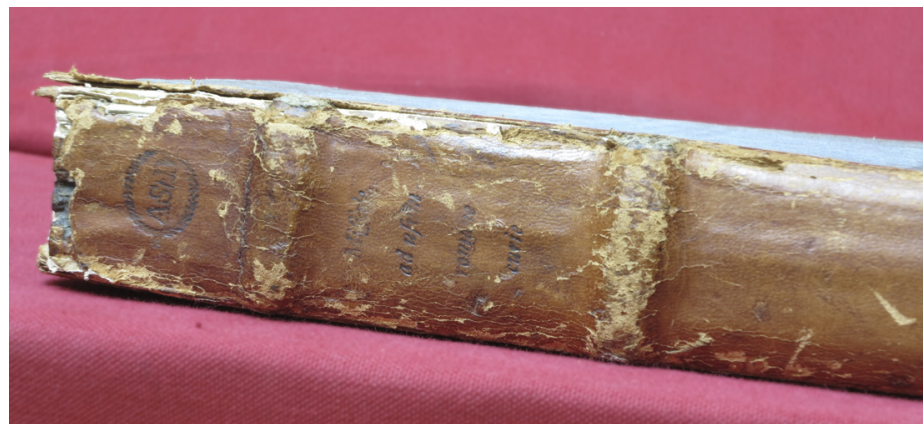

Ryggen af bindet med titlen Missale ad usum romane curie

halvbind af bogbinder Sadolin og dermed reddet for eftertiden.

Stiftsbiblioteket blev senere lagt sammen med Aalborg Katedralskoles bibliotek og huset der. I 1942 besluttede Katedralskolen at sælge et stort antal af dets gamle bøger til Rosenkilde og Baggers antikvariat. En liste over bøgerne blev forelagt Undervisningsministeriet, der hørte både Universitetsbiblioteket og Det Kongelige Bibliotek. Universitetsbiblioteket fik en del af bøgerne, mens Det Kongelige Bibliotek alene ønskede at få to inkunabler, missalet og en kommenteret bibeludgave, til eftersyn. De blev indsendt til KB, hvor overbibliotekar Carl S. Petersen som chef besluttede, at KB ikke $ø$ nskede at erhverve dem, formentlig fordi man havde bibel udgaven i forvejen og fandt, at inkunablen havde visse mangler. En indiskretion afstedkom en ret voldsom avisdebat vedrørende bibeludgaven, mens missalet uden yderligere formaliteter blev solgt af Rosenkilde og Bagger, vist nok til litteraturhistorikeren, professor Paul V. Rubow (1896-1972), på hvis auktion i 1972 det blev købt af Jørgen Jark.

Man kan nu med god ret undre sig over at finde et katolsk missale i et protestantisk kirkebibliotek. En meget nærliggende og plausibel forklaring er imidlertid, at Frederik 2. i 1575 godkendte, at en samling bøger, der stod i det gamle Helligåndskloster i Aalborg, blev overført til Skt. Budolfi Kirke som supplement til det nygrundede bibliotek. Selvom missalet, i modsætning til nogle få andre bevarede bind, i sin nuværende tilstand ikke selv bærer konkret vidnesbyrd om sit tidligere tilhørsforhold til det katolske Helligåndskloster, må det jo være en nærliggende tanke; og den understøttes da også, ved at netop Helligåndsklostrene stod i direkte relation til romercurien og derfor anvendte samme liturgisk tradition. Og i så fald er der hermed tale om, at KB har sikret sig endnu et af de relativt få bevarede bind, der har været her i landet siden middelalderen.

Missalet er nu katalogiseret som Inc. Haun. 4227 Fol.

Det skal for god ordens skyld bemærkes, at trykket må anses for meget sjældent. Der findes et (komplet) eksemplar i Wien, og måske et i Toulouse, men f.eks. ikke i Bibliothéque nationale de France i Paris eller i Vatikanbiblioteket.

\section{Noter}

1 Se f.o.f. L. Nielsen: Dansk Stofts- og Skolebiblioteker, deres historiske Udvikling og deres nuvarende og fremtidige Stilling. 1925; Svend Dahl, "Stiftsbiblioteker", Nordisk Leksikon for Bogvasen. II. 1962. 